\title{
Manuscript Collections: The Cowles Family Publishing Legacy in the Drake Heritage Collections
}

\author{
PATRICIA N. DAWSON
}

Editor's note: In the late 1970s the Annals of Iowa began a series of articles about manuscript collections of interest to people who care about Iowa history. Those articles ran intermittently until about 1990. We are happy to revive the series with this article about the lives and archival collections of one of Iowa's most noteworthy families - the Cowles family.

THE COWLES FAMILY COLLECTION, held by Cowles Library, Drake University, includes materials from three branches of the publishing empire that began in Iowa in 1883: the John Cowles Collection, the Gardner Cowles Jr. (Mike) Collection, and the David Kruidenier Jr. Collection. The twenty-plus filing and storage cabinets in Cowles Library Special Collections contain a fascinating and diverse representation of the media world from the 1930s through the 1990s. This collection of papers and artifacts reflects a true family enterprise from a bygone era. This article offers biographical information on the three journalists in addition to the story of the patriarch of the family, Gardner Cowles Sr. ${ }^{1}$ A summary description of the contents of the individual collections follows each biography. ${ }^{2}$

1. I gratefully acknowledge Herb Strentz and Bart Schmidt for their contributions to the biographies.

2. Cowles correspondence is also on file in the Herbert Hoover Presidential Library in West Branch, Iowa, and the Dwight D. Eisenhower Presidential Library in Abilene, Kansas. Correspondence with Wendell Willkie is at the Indiana University Library in Bloomington, Indiana.

THE ANNALS OF IOWA 73 (Spring 2014). (C) The State Historical Society of Iowa, 2014. 


\section{Gardner Cowles Sr., 1861-1946}

No account of the Cowles family publishing legacy would be complete without some discussion of the man who started it all, Gardner Cowles. Born of humble means in the shadow of the Civil War, Gardner built the foundation on which the Cowles media empire would grow and thrive. His story is one of success and influence in business, politics, and publishing. Every corner of the state of Iowa has felt the influence of the man, his publications, or the foundation that continues to bear his name.

Gardner Cowles was born February 28, 1861, in Oskaloosa, Iowa, to William Fletcher Cowles, a Methodist minister, and Maria Elizabeth LaMonte. When Maria married William in 1857, he was already a widower with three children. She gave birth to Gardner in 1861 and to his brother LaMonte two years later. Unfortunately, she died at the age of 35 when Gardner was just 12 years old. Methodist ministers were transferred frequently, so Gardner's family moved every year or two, living in a variety of Iowa towns, including Albia, Eddyville, Grinnell, Knoxville, Mount Pleasant, Muscatine, Oskaloosa, and Ottumwa.

Gardner spent his first year of college at William Penn College in Oskaloosa. He moved to Grinnell for the next two years of his studies before finishing up at Iowa Wesleyan College in Mount Pleasant. He received a bachelor of arts degree from Iowa Wesleyan in 1882 and a master of arts three years later. Gardner's noted frugality came to light during his college years, most famously when he went a whole year wearing the same suit. While at college, Gardner supported himself by working as a teacher. After graduation, he took the position of superintendent of schools in Algona. During his tenure there, he met Florence Call. They married in 1884. During his time as school superintendent, Gardner bought a half-interest in the weekly Algona Republican.

In 1884 Gardner left the newspaper and education fields to go into business with his father-in-law, Ambrose Call, a wellknown Algona banker. Between 1885 and 1903 Gardner focused on business, capitalizing on Iowa's rapid development. He speculated on land, managed investments, and became involved in banking. By 1900, he had controlling interests in ten different banks in northern Iowa. He also had a strong interest in politics. 
Between 1899 and 1903 he served as a Republican member of the Iowa state legislature.

In 1903, when the Des Moines Register and Leader came up for sale, Harvey Ingham, who edited the paper and owned a minority investment in it, contacted his old friend Gardner Cowles. Ingham convinced Gardner, who by that time was 42 years old and wealthy, to move to Des Moines and purchase a paper that was $\$ 180,000$ in debt and had a circulation of about 14,000 . So, in 1904 Gardner, his wife, Florence, and their six children Helen, Russell, Bertha, Florence, John, and Gardner Jr. (Mike) relocated from Algona to Des Moines. The Cowles family was in the publishing business. ${ }^{3}$

With Ingham's help, Gardner worked tirelessly to fix the paper's problems. By 1906 he had reduced the company's debt and doubled the paper's circulation. He introduced a variety of innovations early on. In his first year he introduced a color comics section for the Sunday edition. His emphasis on home delivery proved successful and allowed the Sunday edition to be distributed outside of Des Moines. In 1908 Gardner purchased the Des Moines Evening Tribune. He renamed his company the Register and Tribune Co. and took on the role of both president and treasurer. Ten years after he had entered the publishing business the Register and the Tribune were reaching about 55,000 readers, over half of whom were outside of Des Moines. The growth of the Register outside of Des Moines was made possible by Iowa's spreading rail network, which allowed the early editions to reach all corners of the state each morning.

As the paper grew, Gardner continued his interest in politics. In 1916 he was an Iowa delegate at the Republican National Convention. His innovations in the newspaper industry continued as the Cowles papers started running public opinion polls created by a young George Gallup. His company was also one of the first newspaper publishers to offer employees group insurance, retirement, and stock purchase plans.

In the 1920s Gardner was able to eliminate his competition in the Des Moines area by purchasing the Daily News from the

\footnotetext{
3. For a history of the Des Moines Register and Tribune Company, see William B. Friedricks, Covering Iowa: The History of the Des Moines Register and Tribune Company, 1849-1985 (Ames, 2000).
} 
Scripps Howard chain in 1924 and buying the Capital in 1927. Both of the purchased papers were merged with the afternoon Tribune, which was briefly renamed The Tribune-Capital. With the Des Moines newspaper market under their complete control, Gardner became chairman of the board of directors of the Register and Tribune Co., with his son Gardner Jr. moving into the position of company president. By that time the papers had grown to be the most influential papers in Iowa, with a combined daily circulation of 350,000 and Sunday circulation of 425,000. By 1928, the Cowles family had expanded into broadcasting, purchasing radio stations in Des Moines, South Dakota, and Washington, D.C.

As Gardner's sons began to take more control over the operation of the family business, he began spending more time golfing, traveling, and playing bridge at the Des Moines Club. He remained busy serving on the boards of trustees at two colleges, a hospital, and several banks. In 1932 President Herbert Hoover appointed him director of the Reconstruction Finance Corporation (RFC). He left his post at the RFC in 1933 and returned home to Des Moines. The following year he and his wife founded the Gardner and Florence Call Cowles Foundation. The foundation is a charitable trust set up to support educational and other charitable institutions in Iowa. By that time Gardner was 73 years old. He suffered from vision problems, so most of his reading had to be done by others for him. As he continued to age, his hearing also failed him. In his last years he could not see at all and was unable to hear much. He could still hear well enough to be read to, and family members read to him constantly. He died February 28, 1946, at the age of 85 .

As his sons took control of the company in the 1930s, they were able to facilitate major growth in the Cowles publishing empire. They expanded into the Minneapolis market in 1935 with the purchase of the Minneapolis Star. Four years later they purchased the Minneapolis Journal, merging the two papers into the Minneapolis Star-Journal. In 1941 the Cowles family took command of all the major papers in Minneapolis with the purchase of the Minneapolis Tribune. In 1937 the Cowles family went on to introduce $L O O K$ magazine to the nation, and several other publications followed. 


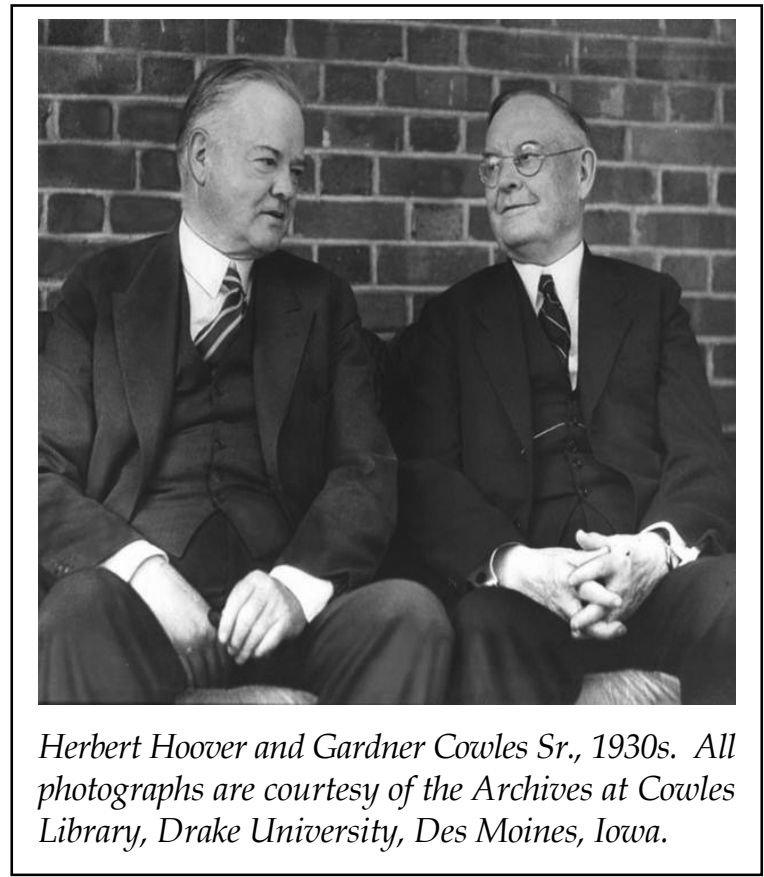

Gardner Cowles Sr. was a success in many different fields, and his family worked to preserve his reputation in publishing. The publications they founded were not only profitable but were also well run and well known for their journalistic integrity. Fifteen years after Gardner's death, journalism educators rated the finest morning/evening newspaper publishers in America. The Cowles papers in Minneapolis and Des Moines were ranked second and third. The prizes and accolades continued; by 1985, the year the Register was sold, it had garnered 13 Pulitzer Prizes - second only to the New York Times.

\section{John Cowles, 1898-1983}

"John Cowles was born with an inexhaustible supply of question marks. In his prime ... . [he] interrogated his friends and colleagues about their views on anything and everythingincessantly, incisively and, some thought, annoyingly," said Minneapolis Star reporter Peter Ackerberg. ${ }^{4}$ Time magazine ob-

4. Peter Ackerberg, "Forever Curious,” Des Moines Tribune, 6/25/1974. 
served in 1935, "No corn-fed bumpkin, no dallying rich-man'sson, inquisitive John Cowles has stored behind his thick-lenses glasses and his moon face a wealth of essential fact. An excellence of perspective on top of a sound judgment makes him one of the most important young newspaper publishers in the land." 5 Kenneth MacDonald, who served more than 50 years at the Register and Tribune as an editor and publisher, attributed the inquisitive nature of both John and Gardner Cowles Jr. (Mike) to their parents. MacDonald said that he never met a more perceptive or more persistent question-asker than Gardner Cowles Sr. At the dinner table, on the road, in the office, at bedtime, and at breakfast, question-asking came naturally to the Cowles boys.

Born in Algona, Iowa, December 14, 1898, John Cowles was not quite 5 when the family bought an interest in the Des Moines Register and moved to their new home. John was the fifth of six Cowles children, to be followed in four years by the youngest, his brother Mike. John attended Des Moines schools before enrolling in the Phillips Exeter Academy, Exeter, New Hampshire, where he graduated cum laude in 1917.

Even with interrupting his studies at Harvard University for a brief training stint in the U.S. Army, he still graduated from Harvard with honors in 1920 and had the distinction of being the first undergraduate to serve simultaneously as an editor of the Crimson, the Lampoon, and the Advocate-the student newspaper, humor magazine, and literary magazine.

Fresh from Harvard, John joined the Register and Tribune as a reporter, covering the Iowa legislature in 1921-his first extended exposure to politics. Only a year later, he organized the Register and Tribune Syndicate, which offered news and features for sale to other newspapers around the nation. That was a somewhat audacious move, since it was a bid to be one of the few successful news syndicates outside New York and Chicago. At its peak, the syndicate offered 60 to 75 features-including such comics and cartoons as "The Family Circus" and "Spiderman" and commentaries by David Horowitz, Stanley Karnow, political cartoonist Herbert Block ("Herblock"), and others. "The Family Circus" was the most successful item, sold to more than

5."Iowa Formula," Time, 7/1/1935, 26. 
1,000 newspapers. The syndicate was sold to Hearst and the King Features Syndicate in 1986 for \$4.3 million.

John became vice-president, general manager, and associate publisher of the Register and Tribune Company in 1923. That same year he married Elizabeth Morley Bates of Oswego, New York, who was to become a significant community leader in Iowa and Minnesota in her own right, in addition to helping to shape John's political views and policies.

From the mid-1920s to the mid-1930s, John and Mike Cowles - who joined the Des Moines papers in 1925-built a record of growth and newspaper innovation that was envied in board rooms and newsrooms around the nation. With their father they were pioneers in newspaper graphics and photojournalism, public opinion polling, building circulation revenue, and developing a reputation for newsroom independence and public service.

In 1935 the Cowles family branched out to Minneapolis. The short version of the story is that the Cowleses looked around for an opportunity to duplicate the success they had enjoyed in Des Moines and in Iowa. In Minneapolis they bought the Star, which had the lowest circulation of the city's three papers - just the situation the Register had been in when Harvey Ingham and Gardner Cowles Sr. bought it in 1903. So, John and Elizabeth Cowles and their four children moved to Minneapolis. Within six years, the Cowleses had built a morning, evening, and Sunday monopoly situation, just as they had in Des Moines by 1927.

The fortunes of the Star were turned around, thanks to strong news coverage and aggressive salesmanship by John Cowles, who dealt with advertisers on a one-on-one basis. A counting-house mentality made some newspapers timid, but the Star attracted and held advertisers and readers as it developed a reputation as the local newspaper that would not yield to advertising pressures or to covering up news. As John summed up his philosophy, reflected in many of his speeches and writings, "Our formula was simply this. Give readers a superior product, deliver it better and promote it effectively." At the dedication of the new Minneapolis Star and Tribune building in 1949, he elaborated, "The primary obligation of a newspaper is to give its readers the news, all the news, without bias or slant or distor- 
tion or suppression in the news columns. We believe that only on our editorial pages should our own opinions be expressed." 6

When the Cowleses purchased the Star in 1935, its circulation was listed at 79,000. With the purchase of the evening and Sunday Journal in August 1939, the combined evening Star-Journal had a circulation of 240,000. Beginning in 1940, it also had a new building, one that Editor and Publisher in 1943 called "the finest newspaper plant between Chicago and the West Coast." 7 Another giant step was announced May 1, 1941: all Minneapolis newspapers were realigned under the Cowles family's command when the Star-Journal purchased the morning and Sunday Tribune. The Times, which had taken the place of the afternoon Tribune, also was controlled by the Cowles family. The purchases reflected another aspect of John's philosophy.

I am convinced that where newspapers have combined or suspended and single ownership newspaper cities or fields have evolved, the resulting product has, in almost every instance, been much superior to the newspapers that preceded it.

I say flatly that with only a small number of exceptions the best newspapers in America are those which do not have a newspaper competing with them in their local field. By best I mean the most responsibly edited, the fairest, the most complete, the most accurate, the best written and the most objective. ${ }^{8}$

The Star reached a peak circulation of almost 300,000 in the early 1960s. The Tribune grew from its 1941 circulation of 61,000 daily and 200,000 Sunday to more than 240,000 daily and 600,000 Sunday. The Tribune and the Star were merged into one publication in early $1982 .{ }^{9}$

John Cowles was also a key player in some of the journalism industry's professional and business associations. In 1929 he was elected a vice-president of the Associated Press (AP) news-gathering cooperative, and he served as an AP director

6. "Cowles Boys Made Amazing 6-Year Record in Minneapolis," Editor and Publisher, 2/13/1943, 7.

7. Ibid.

8. John Cowles, "The Responsibility of a Free Press in a World in Crisis," an address at the 43rd Annual Journalism Week, University of Missouri Bulletin 52, no. 33, Journalism Series no. 124, 7.

9. Obituary of John Cowles, Star and Tribune, 2/26/1983. 


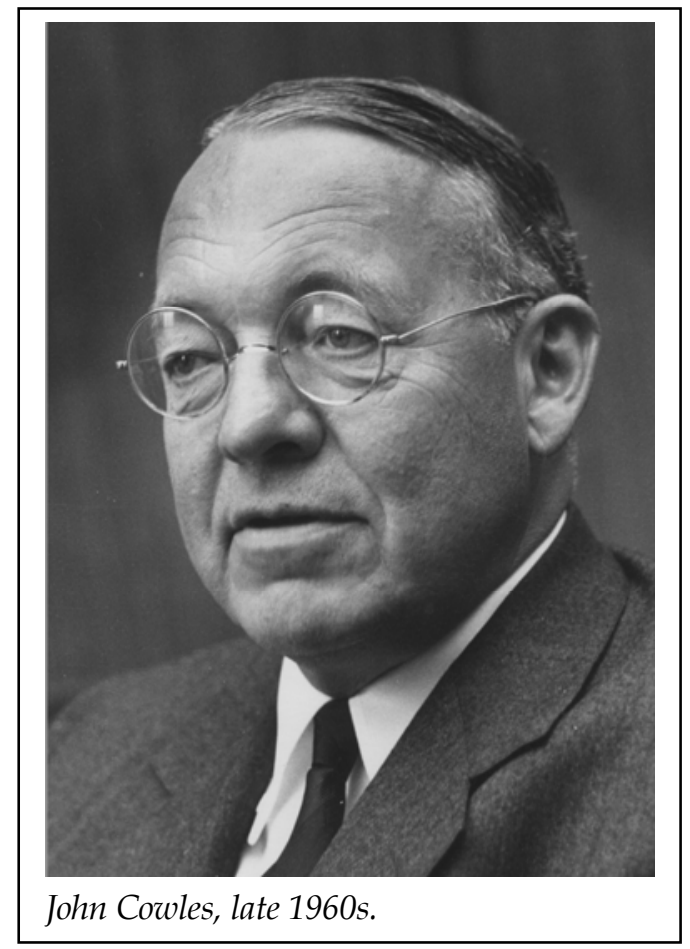

from 1934 to 1943. He was a director of the Audit Bureau of Circulation from 1929 to 1933 . His 1956 honorary doctorate from Harvard, one of ten he received, recognized him as "a journalist with a public conscience." 10 That same year he received the Minnesota Award from the University of Minnesota for distinguished service in journalism.

A prolific writer and world traveler, John often returned from his journeys to produce a series of articles offering insights into developments in Russia, Asia, Europe, England, and South America. A sampling of his essays and commentaries suggests that many of his insights have held up well. Consider, for example, his 1951 comments at the advent of the television age, a good 40 years before talk shows and "news discussion" panels (that are usually rhetorical brawls) became a prime component of television news.

10. His other honorary degrees were from Coe, Simpson, Grinnell, and Drake in Iowa, Macalester in St. Paul, Jamestown in North Dakota, Boston College, the University of Rochester in New York, and Allegheny College in Pennsylvania. 
There is considerable reason to believe, I think, that television, when its facilities become nationwide, when telecasts are in color, and when the number of receiving sets has doubled, will become the nation's single most powerful instrument for the mass transmission of ideas and entertainment. ...

Because of its powerful impact, television may tend to make the maintenance of our free society more difficult. Badly informed, emotionally adolescent TV viewers may tend to adopt hysterically extreme views on complicated political and economic issues concerning which they know, and would otherwise care, little. . . . Television may be the greatest potential agency for adult education we have, but there is a grave danger that it will develop in a pattern where it will not serve the public welfare as it might. ${ }^{11}$

The comment about television hints at the link between John's newspaper career and his involvement in politics and service in the administrations of five presidents: Roosevelt, Truman, Eisenhower, Kennedy, and Johnson. His speeches and articles often consider the newspaper to be a classroom, an educational institution, for citizens; he also likened the role of the publisher to that of the nonpartisan government servant. Cowles expanded on this thought, as it regards newspaper publishers, in a letter in 1963 to J. Edward Gerald.

I have never had any interest in personal participation in party politics, and I think any newspaper is seriously injured if its head does involve himself in partisan politics. I worked for [Wendell] Willkie's nomination only because I thought it was an extremely critical time for the country and that it might be fatal if an isolationist who would not build up the country's military capabilities were elected. When a newspaper editor or publisher accepts any important political appointment, the Administration assumes that his publication will automatically editorially support it. In two administrations I had been asked if I would accept an ambassadorship or other high federal office, but unhesitatingly declined. A newspaperman who accepts such an office loses not only his own independence, but that of his publication as well. This does not mean, however, that I think newspaper executives should not be willing to take temporary non-partisan appointments if they think their services may be in the public interest. For example, F.D.R.

11. Cowles, "Responsibility of a Free Press." 
asked me to serve on the Foreign Bondholders Protective Council, which was to advise the government and the bond owners as to what, if anything, should be done about all of the foreign bonds sold in this country that had gone into default. President Truman asked me, I assume at the suggestion of, or certainly with the advance approval of, Herbert Hoover to serve on the subcommittee of the Hoover Commission which was devoted to proposed changes in our military establishment. This was an important assignment and indirectly resulted in some basic improvements in our defense setup. Truman also appointed me to the White House Conference on Public Education. Eisenhower made me a part-time consultant to the National Security Council shortly after he took office. President Kennedy appointed me to the General Advisory Committee of the Arms Control and Disarmament Agency. ... I know of no reason why newspaper editors or publishers should not take temporary, non-partisan jobs of these kinds. ${ }^{12}$

The most significant recognition Cowles received for such national service was the Medal of Merit, the highest U.S. government decoration for civilians for war service. He received it from President Truman in 1947 for his service in Washington, North Africa, and England in 1943 as a special assistant to the Lend-Lease administrator, E. R. Stettinius Jr.

John's philosophy of public service applied, too, to private organizations and foundations. Perhaps the position he prized most was his role as a director of the Ford Foundation, to which he was appointed in 1950. His views on world affairs, he said, were greatly influenced by Paul Hoffman, the Ford Foundation president and former director of the Marshall Plan. Some of John's international travels were on behalf of the Ford Foundation. John also cited his education at Harvard and editor Harvey Ingham as being influential in shaping his political and social views.

Another important influence on John's life and career was his wife of 53 years, Elizabeth, who died in 1976. In the 1930s she was a founder of the Maternal Health League (which later became Planned Parenthood) in Iowa. She was primarily re-

12. Folder of material gathered by J. Edward Gerald from interviews with John Cowles regarding his life and career, mostly notes from 1961-1963, drawer 4, cabinet 23, John Cowles Collection, Cowles Library, Drake University, Des Moines. 
sponsible for the opening of the state's first birth control clinic in 1935. She continued her Planned Parenthood work in Minneapolis, along with memberships in the American Civil Liberties Union, the League of Women Voters, and other civic organizations. She was a charter member of the United Negro College Fund and a lifetime member of the National Association for the Advancement of Colored People.

In a 1974 profile by Peter Ackerberg, John said that he by then regarded himself as "an independent with Democratic leanings." "As I've learned more," he added, "I've become more liberal." Partly responsible for that "learning," John said, was Elizabeth Cowles. ${ }^{13}$ The couple was also a strong supporter of the arts in Minneapolis and Des Moines. They had two daughters (Morley Cowles Ballantine of Durango, Colorado, and Sara Cowles Doering of Cambridge, Massachusetts), two sons (John Cowles Jr. of Minneapolis and Russell Cowles of Minneapolis), and 16 grandchildren.

John's service to private corporations and foundations and universities included being a trustee or director of the Carnegie Endowment for International Peace, the American Assembly, the Minneapolis Society of Fine Arts, the Minneapolis Foundation, General Mills, General Electric Co., Equitable Life Insurance of Iowa, the Gardner and Florence Call Cowles Foundation, Harvard University, Phillips Exeter Academy, Carleton College, and Drake University.

John was chairman of the board of the Des Moines Register and Tribune Company from 1945 to 1970 . He was president of the Minneapolis Star and Tribune Company and predecessor companies from 1935 to 1968 and chairman from 1968 to 1973.

THE JOHN COWLES COLLECTION includes 16 filing cabinets of papers and other memorabilia and framed documents and photographs. The material is organized and cataloged in such a way as to preserve as much as possible the original placement of papers in John's files. If the placement of an item seems strange to the researcher, it is probably where it is because John Cowles caused it to be there. The following general areas are listed in the order of their filing in the file cabinets:

13. Ackerberg, "Forever Curious." 
Speeches: These files include speeches made by John Cowles, correspondence relating to the speeches, and material he kept for reference when writing speeches, organized by date where relevant.

Family: These files include correspondence with family members, family business matters, art, insurance, philanthropy, estate business of both John and Elizabeth Bates Cowles and other family members, foundation matters, investments, and trusts.

Special Areas: Papers relating to Phillips Exeter Academy, the Ford Foundation, General Mills, Harvard University, the Des Moines Register, Look magazine and Cowles Communication, Inc.

Public Life: These papers are organized chronologically, with the years up to 1955 being mostly a year-by-year set of files. After 1955, the files are alphabetical by subject with a range of dates given for each file. This organization is the way the material was originally found.

Artifacts: This category includes material that either did not arrive at the library in a file folder or did not lend itself to storage in a file folder. Included are rolled documents, academic hoods, scrapbooks, photographs, and published materials.

The online index lists the number of the filing cabinet and the number of the drawer.

\section{Gardner Cowles Jr. (Mike), 1903-1985}

Judging from his life, no one ever told Gardner Cowles Jr. (Mike) that being a newspaper editor and publisher should not be fun. Mike Cowles asked so many questions, told so many stories, and exhibited such a joie de vivre that any observer could see his enthusiasm for his career. Here was a person loyal to family traditions in responsible, public-spirited, and innovative journalism. But Mike was also a person who enjoyed working with a young George Gallup to determine reader interests, was a pioneer in photojournalism, mingled with celebrities, took the measure of the movers and shakers of his time, and still had the whimsy to own for a few years the Cardiff Giant - the gypsum carved giant created for a successful 1869 hoax.

Mike Cowles and the Cowles family brought to American newspaper journalism a tradition of innovation, newsroom independence, and community service that typically are part of the definition of the family-owned, regional newspapers of an 


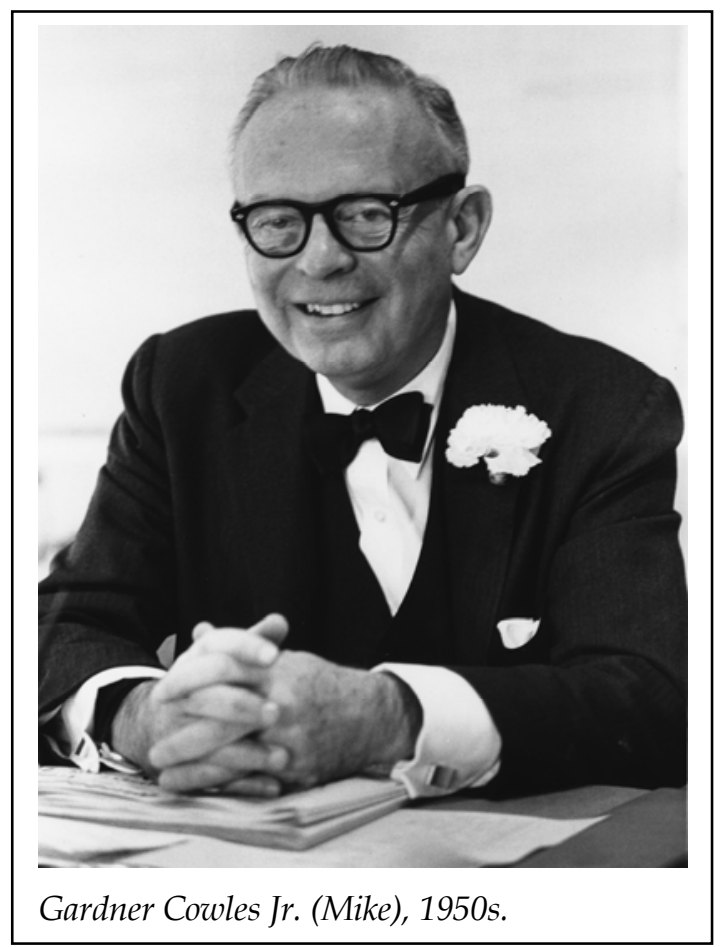

almost bygone era in journalism history. As noted by Fortune magazine in 1950, "There is nothing in the Cowles' record to indicate that the family ever lusted after power or profits. They were a dyed-in-the-wool newspaper family with an urge, above all, to produce a paper that would honor their craft." 14

Mike Cowles was born on January 31 of the year of the Register purchase and died in 1985, just one week after the Register was sold to Gannett Co. Inc. after 82 years of Cowles family ownership. He was the third son and last of six children of Gardner Cowles and the former Florence Call. His older brothers were Russell, who became a well-known painter and muralist, and John, his compatriot in many publishing ventures; his three sisters were Helen Cowles LeCron, Florence Cowles Kruidenier, and Bertha Cowles Quarton. In his memoir, Mike Looks Back, he

14. George Mills, Harvey Ingham \& Gardner Cowles, Sr.: Things Don't Just Happen (Ames, 1977), 87. 
explains his nickname: Although named Gardner Jr., he carried the name of Mike ever since he was a day or two old, he said, after his father "took a good look at me and announced 'He looks like an Irishman. Let's call him Mike.'"15 (Mike kept that family practice alive by dubbing his son Gardner Cowles III "Pat").

Mike attended public schools in the city and, when he was 15, went to Phillips Exeter Academy in Exeter, New Hampshire, with the expectation that Harvard would come next-as he followed in the footsteps of his brother John. At Exeter, Mike was editor of the weekly paper, the Exonian. At Harvard, from which he graduated in 1925, he was the editor and president of the student daily newspaper, the Crimson.

When he joined the Des Moines Tribune soon after graduation and then switched to the Register, he was on familiar ground. Almost as far back as he could remember he had been at the papers. When he was 8 , his father paid him 25 cents for each editorial he proofread, and while at Harvard he had worked summers as a Register reporter.

One of his first assignments as a full-time reporter was covering the legislature and the Register's campaign to "get Iowa out of the mud." In 1920 the state had about 25 miles of paved highways; by 1930, the paved mileage was 3,272-the precision of the measure was attested to by a map kept outside Gardner Cowles's office on which each new paved mile was colored in crayon. The paved roads not only got Iowa out of the mud but also worked well with Gardner Sr.'s efforts to circulate the Register throughout Iowa.

Mike said that his mother was the greatest influence on his life, through her liberal social views, humor, and soft-spoken nature. He and his brother John learned the newspaper business well from their father, but much of the influence on Mike as an editor came from Harvey Ingham. Ingham was who Mike said he had in mind when in 1955 he spoke about what makes a great editor: "The greatest editors I know are just like the greatest educators and are successful for the same reason. They are thoughtful men with scrupulous regard for the truth. They are men who strive to stir the best in the human race, not pander to the worst.

15. Mike Cowles, Mike Looks Back (New York, 1985), 7. 
They are men who dare to lead, even when the direction is temporarily dangerous and unpopular." 16 Mike had sounded a similar theme several years before, in a 1949 comment.

The only answer to ignorance is education and more education. And I mean more than just the formal education in more and better schools, colleges and universities. I mean more adult education, more public forums, more discussion groups. But above everything else, I mean better newspaper and magazine editing, better news and discussion and debate programs on the radio. And I mean the use of the powerful new medium of television to make people understand and think. ${ }^{17}$

His concept of education mirrored a personal ethic of learning that was built on meeting people and asking questions. Friends would invariably speak of his insatiable curiosity that would elicit information from people and a gregarious nature that relished meeting new people and sharing ideas and stories. His most noted questioning episode came in 1959 when he irritated Russian leader Nikita Khrushchev by persisting in a question about freedom of expression in Russia. Speaking at the Economic Club of New York, Khrushchev had called for Americans and Russians to become better acquainted. "That being your feeling," Cowles asked, "why do you insist on censoring the dispatches of American correspondents in the Soviet Union?"18

In the late 1920s and the early 1930s, Mike had moved through various newsroom executive positions, apparently informally and fast enough so that his own recollections and newspaper records simply list the positions as being held in succeeding years as city editor, news editor, associate managing editor, managing editor, executive editor, and associate publisher. He listed the title of publisher, too, along the way. What is clear is that he was Register and Tribune president from 1943 to 1971 and chairman of the board from 1971 to 1973.

16. Mills, Ingham $\mathcal{E}$ Cowles, 112.

17. Mike Cowles, "Freedom \& Responsibility," speech at the Des Moines Register and Tribune centennial banquet, Des Moines, June 20, 1949, Gardner Cowles Jr. (Mike) Collection, Cowles Library, Drake University, Des Moines.

18. Mills, Ingham \& Cowles, 111. 
His innovations and impact on journalism were more important than the publishing titles he carried. His father, who would be publisher until his death at 85 in 1946, gave him some latitude. In fact, some credit Mike and John with more than doubling Register and Tribune circulation in the 1920s from 110,000 to 243,000 daily for the two papers and from 86,000 to 206,000 on Sunday. Under Mike's leadership, the Sunday Register's circulation rose from 168,271 in 1928 to 376,372 in 1941.

In the late 1920s Mike, then about 25, teamed up with a doctoral student from the University of Iowa, George Gallup, then about 27. Gallup, who was teaching at Drake University at the time, conducted some of the nation's first readership studies for the Register and Tribune. What he and Mike found confirmed Mike's interest in photojournalism. Gallup showed that any use of graphics would increase readership of a news item and that readers preferred a series of photos on a related subject to photos on different topics. Based on that research and his own passion for pictures, Mike greatly expanded the use of photos in the Register and Tribune and pointed with pride to a finding that in one six-day period the Tribune carried more photographs than any other leading newspaper in the nation. He credited the Sunday Register's rotogravure section with helping get the newspapers through the Depression.

Despite the lean economic times of the 1930s and the fact that the papers were barely breaking even, Mike chose Richard Wilson, then 28 and the Register's city editor, to open a Register and Tribune news bureau in Washington, D.C., in 1933. An editorial noted that such a Washington outpost was needed because "it is the obligation of these papers to the state to give such news service from every quarter ... and that applies with particular force to Washington news with an Iowa slant." 19 That philosophy was consistent with the paper's slogan that it was "The Newspaper Iowa Depends Upon." It also was consistent with the nature of the family-owned, privately held newspaper to have priorities other than the bottom line. Over the years, Washington bureau reporters won five Pulitzer Prizes for the Register, including one by Wilson in 1954.

19. Ibid., 144. 
Mike combined two of his passions - photography and aviation - with the development of aerial photography. The Register, beginning as early as 1928, had its own airplane, named the Good News after a reader contest. The aerial photography combined with a "machine-gun" camera-developed by photographers George Yates and Charles Gatschet in 1935 for rapid-fire exposures-made the Register and Tribune national leaders in photojournalism. The availability of the Good News improved Register and Tribune news coverage of the region, especially on fast-breaking stories. Mike also increased sports coverage in the papers and, thanks to Yates's camera, provided sports page readers with an early day version of instant-replay as key plays in football games were pictured in detail across the sports section. ${ }^{20}$ The aerial photography in the Register was developed to its fullest extent under Don Ultang, a pilot and photographer for the paper from 1946 to 1958.

Recognizing the onset of the age of aviation, Cowles urged airport development in Des Moines. In 1936 he spent his own money to ensure that land would be available for airport expansion in Des Moines when the city had the public authorization and the money to do so. The 160 acres that he purchased for $\$ 70,000$ was transferred to city ownership at cost. His leadership in airport development continued into the 1940s.

In 1938 John moved to Minneapolis to take over as a fulltime resident publisher while Mike stayed in Des Moines to, in his words, "look after The Register and Tribune and to develop my plans for LOOK magazine." 21 Based on responses to the photo coverage in their newspapers and the sale of photo features to other newspapers, Mike decided in 1936 to start a national picture magazine to be called LOOK, a name suggested by his mother. Upon hearing that Time and Henry Luce had similar plans for a magazine to be named LIFE, the Cowles brothers met with Luce and Roy Larsen of Time to compare

20. One such series of photographs ignited a nationwide controversy about the treatment of African American college football players and earned Don Ultang and John Robinson a Pulitzer Prize. See S Zebulon Baker, " 'This affair is about something bigger than John Bright': Iowans Confront the Jim Crow South, 19461951," Annals of Iowa 72 (2013), 122-31, 139-52.

21. Mike Cowles, Mike Looks Back, 41. 


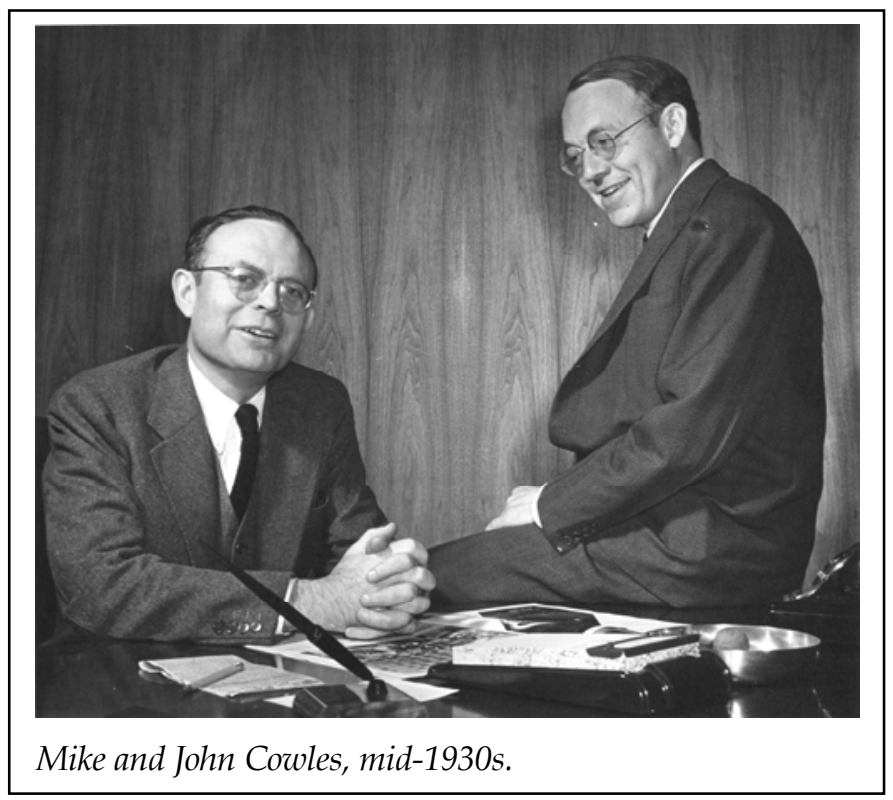

notes. The plans for LIFE to be a weekly with a news orientation while $L O O K$ was intended to be a feature-oriented monthly magazine were different enough that the brothers thought there was room in the market for both. They decided to see how LIFE fared before entering the magazine field, which they did a year later, with the first issue of LOOK published January 5, 1937.

Meanwhile, both the Minneapolis and Des Moines newspapers continued to emphasize newsroom independence from advertising and political pressures. In Minneapolis, soon after the Cowleses assumed ownership of the Star, the business community was upset when the Star refused to join its two competitors in ignoring the news about a well-known executive arrested for violating hunting laws. In Des Moines the papers from time to time suffered economically from advertising boycotts in protest of news coverage.

In part, the Cowles brothers argued that monopoly ownership such as they enjoyed in both cities - after 1927 in Des Moines and after 1941 in Minneapolis - enabled them to resist pressures to sensationalize or censor the news. But resistance to advertising, personal, and political pressures-including those of the railroad 
and liquor interests - had been established early in the leadership of the senior Cowles and Harvey Ingham. In 1915 Ingham had written,

Two avenues of popularity are open to the newspaper. The first is to yield to flatter, to cajole. The second is to stand for the right things unflinchingly and win respect. . . . A strong and fearless newspaper will have readers and a newspaper that has readers will have advertisements. That is the only newspaper formula worth working to. ... After making all allowances the only newspaper popularity that counts in the long run is bottomed on public respect. 22

In family-owned newspapers, newsroom and family traditions were intertwined. David Kruidenier, the son of Florence Cowles Kruidenier who in 1971 succeeded Mike as president of the Register and Tribune Company, said that newsroom independence "is bred into one. I come off this heritage." 23

Such lessons found believers in the newsroom, too. In a rare instance in which the senior Cowles might suggest that a story be played inside the paper instead of on page one, the newsroom had the confidence that it could play the story on page one and not hear a word about it. Newsroom independence was based on the confidence that the Cowles family had in its editors and staff so as not to second guess them or to risk losing them. Kenneth MacDonald, himself a newsroom leader as editor and publisher during his 50 years with the Register and Tribune Company, thought that one root of the newsroom independence stemmed from Gardner Cowles's respect for Jay ("Ding") Darling, the Register's cartoonist from 1906 to 1949, except for a brief fling in New York, 1911-1913. Politically, Darling was far more conservative than Ingham, and Cowles devoted considerable time to keeping peace between them. To bridle Darling might mean losing him. So Darling was an independent cartoonist who contributed Pulitzer Prizes to the Register in 1924 and 1943.

Mike Cowles continued the tradition of newsroom independence, relying on editors like Ken MacDonald and editorial

22. Ibid.

23. Quoted in Mills, Ingham \& Cowles, 40. 
page editors like Bill Waymack, Forrest Seymour, and Lauren Soth - all Pulitzer Prize winners (1938, 1943, and 1956) - to set the newspaper's agenda. At a dinner marking MacDonald's retirement in 1977, Mike shocked those editors and longtime staffers present by noting that he never did agree with the Register's editorial policies on agriculture and then spelled out what he thought the policy should be. Some of those present thought that maybe Mike was overstating his disagreement-but the point was made: a paper could, perhaps should, have editorial stands different from its publisher's. That point was made, too, when, as editorial page editor of the papers in the 1970s and early 1980s, Gilbert Cranberg opposed a downtown business development plan supported in part by then publisher David Kruidenier. To Des Moines business interests such policies were puzzling; to the Cowles family it was the way to run a good newspaper.

Not that Mike and John Cowles were political wallflowers or uninvolved in their communities. Their fascination with politics included a belief that it was their duty as citizens to be involved. Their strong support for Wendell Willkie's presidential candidacy in 1940 was so public and so impassioned that on a swing of Willkie's through Minneapolis and Des Moines, the news coverage in the Cowles papers was almost fawning. A review of correspondence and the news coverage suggests that the favorable coverage was not a result of the overt direction of either of the Cowles brothers, but because the reporters perceived that Willkie was the bosses' candidate. Correspondence between Mike and Willkie suggests that Mike did wield a heavy hand, however, in LOOK magazine, giving Willkie a strong boost.

The Cowles brothers were intimate advisers of Willkie during his drive for the GOP nomination and his campaign against President Roosevelt. They remained so after the election. The brothers hoped to lay the groundwork for another Willkie bid in 1944-an effort with little hope of fruition at the outset and no hope ultimately because of GOP disaffection with the liberal Willkie and then an illness that incapacitated Willkie in mid-1944 and led to his death that October. The largest single memorial to Willkie was a gift of $\$ 125,000$ from the Gardner Cowles and Florence Call Cowles Foundation to establish Willkie House, 


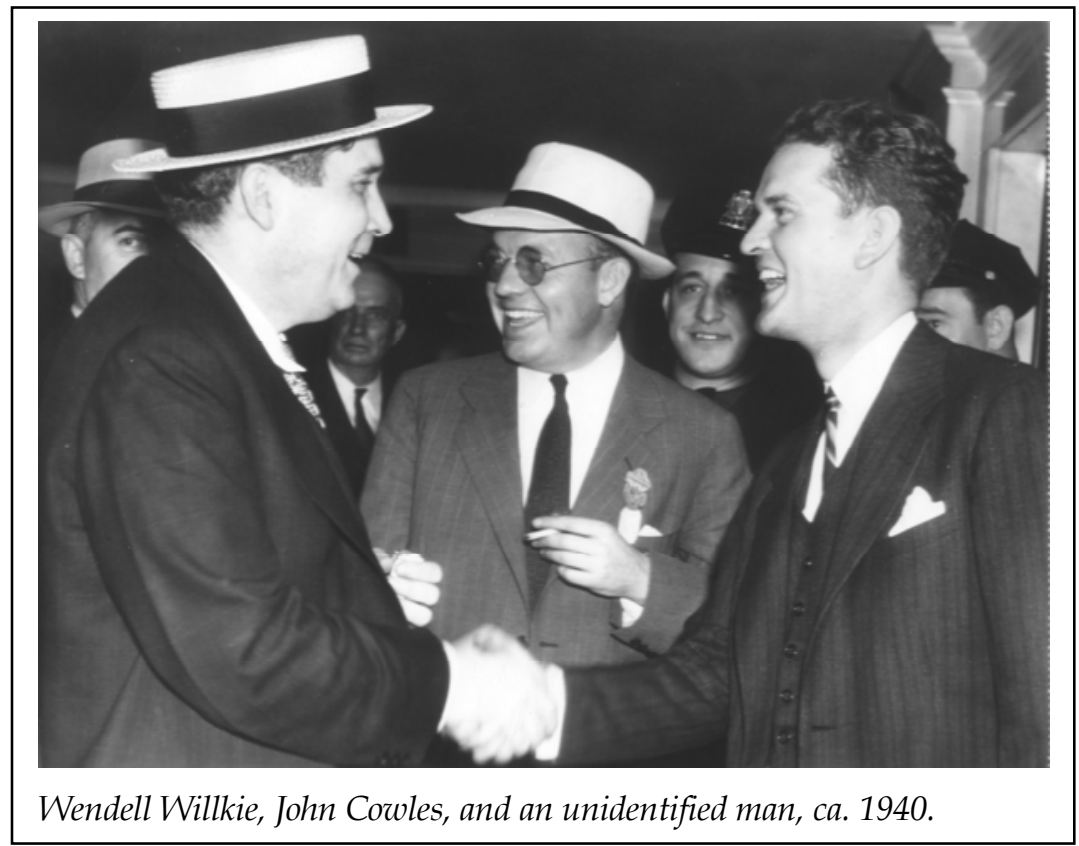

an African American community center in Des Moines, a memorial that reflected both Willkie's and the Cowleses' concerns with civil rights and race relations.

The links between the brothers and Willkie had been forged even stronger after the 1940 campaign. John accompanied Willkie to England in January 1941 on a bipartisan journey requested by President Roosevelt. FDR wanted to rally congressional support for the U.S. Lend Lease program to provide the Royal Navy with more ships in its war against Nazi Germany. Willkie's testimony before Congress helped ensure congressional approval of Lend Lease. Almost two years later, Mike accompanied Willkie on his 49-day "One World" tour - a trip again supported by Roosevelt to assure U.S. allies of strong bipartisan support in the United States for the war effort. Mike was in the small Willkie party that carried the unity theme to Allied leaders in Africa, the Middle East, Russia, and China from late August to midOctober. Mike called the trip the highlight of his life.

The "One World" journey came soon after Mike had been appointed to wartime duty as assistant director of the Office of 
War Information (OWI). His responsibilities in the OWI were to direct a domestic news bureau, coordinating information from non-military government agencies. Mike took the job in response to a short request from President Roosevelt, a note that said, "Dear Cowles, Please do! FDR." Cowles served in the OWI for about a year under the leadership of Elmer Davis.

Mike's interest in international issues and in aviation led to occasional around-the-world tours and frequent trips to Europe - one of which included a trip home aboard the airship Hindenburg a year before its explosion on May 7, 1937, in Lakehurst, New Jersey. But, as with the Willkie trips, there was little news coverage in the Cowles papers about such journeys. As a matter of newspaper policy and what they saw as journalistic decorum, the Cowles family shunned news that might be viewed as selfpromotion. The Register and Tribune did cover Mike's speeches to community business and educational groups when he spoke about political trends.

In the post-World War II years, Mike's business and personal interests moved him to New York, fulfilling a boyhood dream, he said, that began when on his first trip to the city as a boy of 12, his father gave him five dollars and turned him loose on the city and Coney Island. Mike navigated the subway system and the rides at Coney Island all day, returning back to the hotel and a relieved mother in the early evening. In New York, he directed $L O O K$ and undertook other publishing and broadcasting ventures while maintaining his leadership at the Register and Tribune.

Mike and John talked on the telephone two or three times per week to keep watch over the Cowles holdings, although their newspapers were separate operations. By the mid-1950s, the Sunday circulations of their Des Moines and Minneapolis newspapers totaled well over a million, covering Iowa and Minnesota and circulating into neighboring states. The Register's peak Sunday circulation was about 550,000, and the paper circulated in each of the state's 99 counties.

LOOK had also been a success, and the publication had been moved to twice per month. The publication reached a peak circulation of about 9 million before falling to television, higher postal costs, and other forces that spelled the end of the mass 
circulation magazine. The most difficult day of his life, Mike later said, was September 16, 1971, when it was announced that LOOK would cease publication on October 19, 1971.

Mike's other magazine ventures included Quick, a pocketsized weekly news magazine, which was started in 1949 and suspended in 1953, when it had reached a circulation of 1.3 million. Although the smaller size was not attractive to some advertisers, the main reason Quick was killed was that its subscribers - if transferred to LOOK-would help LOOK maintain an important subscription edge in a critical circulation battle with Collier's. Flair, a magazine pressed upon Mike by his third wife, Fleur Fenton, had so many special design elements that, although interesting, it lost about 75 cents per copy and was suspended one year after its debut in January 1950. Venture, a travel magazine published from 1963 to 1967, featured a threedimensional photograph on each month's cover.

On the newspaper front, seeing the opportunity for a daily newspaper serving Long Island, Mike started the Suffolk Sun on November 21, 1966. The Sun survived for only three years, with publication suspended October 18, 1969. A longer-lasting venture was the San Juan (Puerto Rico) Star, established November 2, 1959, and sold to Scripps Howard August 12, 1970. The Des Moines Tribune was among the afternoon newspapers falling almost like dominoes in the early 1980s; its last issue was September 25, 1982. Similarly, in the frenzy of newspaper buying in those years, a bidding war for the Des Moines Register resulted in the sale to Gannett in 1985 for about \$200 million, leaving the Minneapolis Star-Tribune as the Cowleses' primary presence in the Midwest. The publisher of the Register under Gannett was Charles Edwards, a nephew of David Kruidenier, the fourth generation of the Cowles family to head the paper, but the first to do so without family ownership.

Mike held honorary degrees from 11 colleges and universities, including seven in Iowa: Coe, Cornell, Drake, Grinnell, Iowa Wesleyan, Morningside, and Simpson. Others were from Bard College, Mundelein, Long Island University, and Hobart and William Smith Colleges. In 1950 he was the chief marshal of the Harvard commencement. He served on the Columbia University Advisory Board on Pulitzer Prizes and the boards of directors 
of R. H. Macy and Company, the New York Times Co., United Air Lines, UAL Inc., Kemperco Inc., Bankers Life Company, First National Bank of Miami, and the American Society of Newspaper Editors, the Magazine Publishers Association, and the National Association of Broadcasters.

Mike was married four times. His first marriage was to Helen Curtiss. They wed in November 1926 and divorced in May 1930. His marriage to Lois Thornburg (May 1933-August 1946) resulted in four children: Lois Cowles Harrison, Gardner III (Pat), Kate Cowles Nichols, and Jane Cowles. The third marriage was to Fleur Fenton (December 1946-November 1955). He was married to Jan Hochstraser (also known as Jan Streate Cox) from May 1956 until his death; with her he had a daughter, Virginia, and a stepson, Charles.

Newspapers, including Cowles family holdings, owned during his life were the Des Moines Register (1903-1985); Des Moines Tribune (1908-1982); Minneapolis Star (1935-1982); Minneapolis Tribune (1941-1982); Minneapolis Star-Tribune (19821985); San Juan (Puerto Rico) Star (1959-1970); Gainesville (Florida) Sun (1962-1971); Lakeland (Florida) Ledger (1963-1971); Rapid City (South Dakota) Journal (1964-1990); Great Falls (Montana) Tribune (1965-1990); Suffolk (Long Island, N.Y.) Sun (19661969); Palatka (Florida) Daily News (1969-1971); Leesburg (Florida) Daily Commercial (1969-1971); Jackson (Tennessee) Sun (19721985); and Waukesha (Wisconsin) Freeman (1978-1983).

THE GARDNER COWLES JR. (MIKE) COLLECTION covers the years approximately from 1942 to 1975 . The papers consist mainly of correspondence, speeches, and material related to the business of publishing. In organizing these papers, observing the rule of provenance resulted in some like material being filed in two different areas -for example, LOOK material both in folders labeled "Look" and in folders labeled "CMI - Cowles Magazines Inc."

The Mike Cowles Collection is divided into four major categories with an addendum for file drawers 21-26:

Correspondence: filed alphabetically by correspondent and date.

Speeches: filed by date. Mike's own inventory of his speeches is filed here with additions by the archivist. The folders include correspondence regarding particular speeches if Mike arranged them in that way. 
General subjects: the remainder of the papers that could be filed in folders, filed alphabetically by topic and including some large groups of folders on such subjects as LOOK magazine and the San Juan Star.

Other materials not suited to file folders.

\section{David Kruidenier Jr., 1921-2006}

David Kruidenier, grandson of Gardner Cowles Sr., was born in Des Moines on July 18, 1921, to Florence Cowles Kruidenier and David Kruidenier, who operated an automobile dealership that sold Cadillacs, Oldsmobiles, and LaSalles. After attending Des Moines public schools through the ninth grade, Kruidenier graduated from Phillips Exeter Academy and Yale University and received a master's degree in business administration from Harvard University. During World War II, Kruidenier served as an Army Air Force officer in the capacity of navigator aboard bombers in the Pacific. He was credited with 34 missions and was awarded the Air Medal with three clusters and the Distinguished Flying Cross. In December 1948 he married Elizabeth Woodwell Stuart, who later became a Des Moines lawyer and civic activist.

Kruidenier's newspaper career began in 1948, when he trained at the Minneapolis Star and Tribune. In 1952 he came to the Des Moines Register and Tribune as assistant business manager, the beginning of a career spanning 33 years and different positions with the paper. In 1960 he became vice-president and general manager, and in 1971 he was named president, CEO, and publisher of the company. He was also president, CEO, and board chairman of Cowles Media Company.

As Register staff writers stated in Kruidenier's obituary in the Des Moines Register,

Under Kruidenier's leadership in the 1970s and early 1980s, the Register sharpened and deepened its coverage of business, politics and agriculture, and won three of its 15 Pulitzer Prizes. Aggressive coverage of business news caused some criticism of the Des Moines newspapers and of Kruidnier personally from people in the business community who labeled the coverage as negative or antibusiness. These critics sometimes went privately to Kruidenier to complain that as top man at the newspaper he should step in and 
either direct that certain stories be done or direct that certain stories be withheld from publication. Kruidenier's response was that a newspaper performs best by not being a mouthpiece for any one point of view and that the community is better off when a newspaper talks openly about the strengths and weaknesses of the community.

In the same obituary, James P. Gannon, editor of the Register, said, "Kruidenier always showed a keen understanding of and appreciation for the need for a vigorous, independent news department. He was a great publisher in supporting the news effort with the needed resources and then leaving it to operate independently. . . . I never saw a single example of any effort on his part to interfere with editors' decisions on handling the news."

In 1985 the Des Moines Register was sold to the Gannett Company for about $\$ 200$ million. When the stockholders of the company approved the sale on July 1, 1985, Kruidenier noted that the action marked "the ending of a partnership between the Cowles family, Des Moines and the state of Iowa that had lasted 82 years." 24

Kruidenier was a director of the Audit Bureau of Circulations and of the Newspaper Advertising Bureau. He was a trustee of Grinnell College and a director of Norwest Bank, Des Moines. He was a member of the board of the Menninger Foundation, Midwest Research Institute, and the Walker Art Center. He was known for his long and vital commitment to the metro area, including the Des Moines Civic Center, Nollen Plaza, Simon Estes Amphitheater, Forest Avenue Library, the renovation of Gray's Lake, and the new downtown public library. As his obituary states, "After leading the fund drive that resulted in the construction of the Des Moines Civic Center, Kruidenier served as chairman of its board of directors for a number of years. He was also a trustee of the Des Moines Art Center for years, and his personal art collection was extensive. Kruidenier was a member of the boards at Iowa Methodist Medical Center, Drake University, the Cowles Foundation, the Gardner and Florence Call Cowles Foundation, Des Moines Chamber of Commerce, Greater Des

24. Des Moines Register, 1/10/2006. 


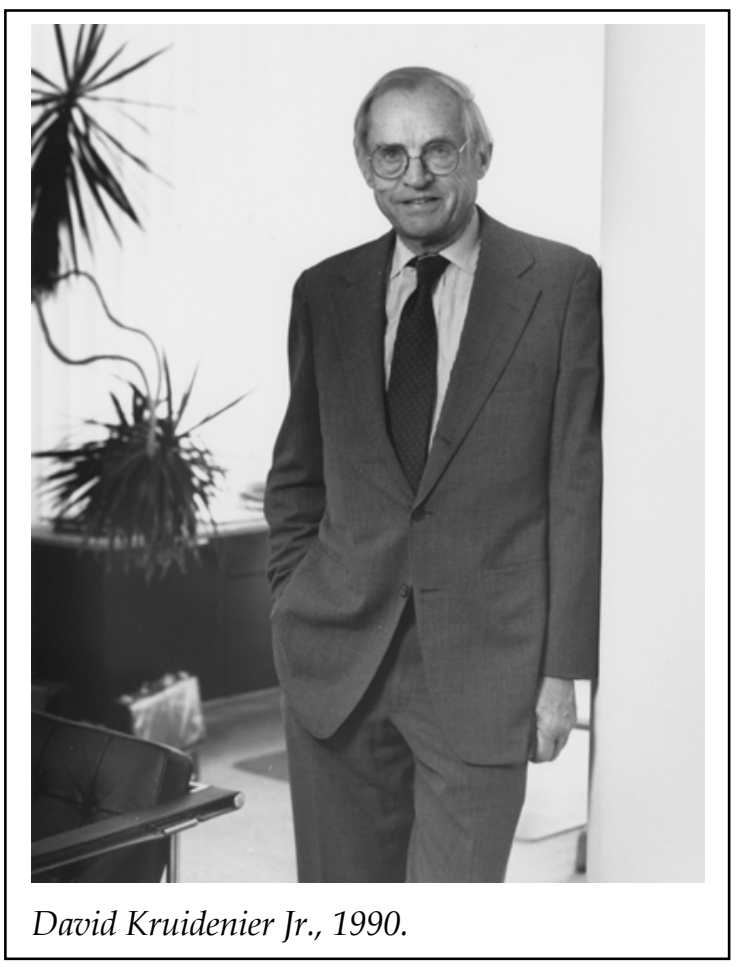

Moines Committee, Des Moines Symphony, and the Civic Music Association. He was a member of the Des Moines Club, Wakonda Club, Rotary Club, Iowa Society for Crippled Children and Adults, Junior Achievement, and the Governor's Committee on Mental Health." 25

David Kruidenier was inducted into the Iowa Business Hall of Fame in 1993 and named one of the state's most influential people in 2000. Other honors include the A. Arthur Davis Award from the Greater Des Moines Leadership Institute, University of Minnesota Distinguished Journalism Award and the Des Moines Philanthropist Award, the 1992 Outstanding Leadership Award from the Des Moines Human Rights Commission, the Des Moines Mid-City Vision Committee Annual Award, and the 1992 Honor Award from the American Library Trustee Association. He received honorary degrees from Buena Vista College (1960), Simp-

25. Ibid. 
son College (1963), Luther College (1990), and Drake University (1990).

THE DAVID KRUIDENIER JR. COLLECTION, housed in three filing cabinets at Cowles Library, includes correspondence, clippings, and other published material and photographs. The material is organized and cataloged in such a way as to preserve as much as possible the original placement of papers in Kruidenier's files. The following general areas are listed in the order of their filing in the file cabinets:

Family: These include files related to the Cowles/Call families, Kruidenier family, correspondence with family members, and history.

Correspondence and Speeches

Des Moines Register: This material includes correspondence, reports, minute books, clippings, and much on the sale of the Des Moines Register in 1984-85.

Cowles Media Company/Minneapolis Star-Tribune: Included here are annual reports, correspondence, and clippings.

Des Moines City Involvement: Folders here contain aspects of Kruidenier's many civic contributions - public libraries, Civic Center, Gray's Lake, Drake University.

RECENTLY, these three collections, which came to Drake at different times, were reorganized and integrated into a searchable database on the Cowles Library site: http://cowles-archon .drake.edu $/ \mathrm{p}=$ collections $/$ findingaid \&id $=266 \& \mathrm{q}$. General information about the collection and family can be found at www.lib.drake.edu/heritage/GardnerCowlesFamily.

This huge collection composite, filling over 20 storage cabinets and covering seven to eight decades of American journalism and publishing history, is a significant source for research on that topic as well as political and business history. The John Cowles Papers, in particular his correspondence, are worthy of investigation. John Cowles was an amazing correspondent; his letters to family members and friends such as Dean Acheson and Archibald MacLeish are filled with references to the important topics of the day, including business matters, economics, politics, and domestic and foreign affairs. These letters are an invaluable source for his ideas and opinions. The papers of all 
three journalists would be useful for studying trends such as photojournalism, television, and magazine publishing.

The papers, letters, and photos of John Cowles, Gardner Cowles Jr. (Mike), and David Kruidenier Jr. are available for viewing at Drake University's Cowles Library by appointment. For assistance, contact the Cowles Library reference desk for hours and additional information: 515-271-2113 or claudia .frazer@drake.edu. 